\title{
Analisis Financial Distress dengan Metode Zmijewski (Studi Kasus pada PT. Jaya Konstruksi Manggala Pratama Tbk, PT. Indonesia Pondasi Raya Tbk dan PT. Mitra Pemuda Tbk Periode 2015-2017)
}

\author{
Desi Permatasari ${ }^{*}$, Acep Samsudin ${ }^{2)}$, Kokom Komariah ${ }^{3)}$ \\ ${ }^{1 * 2,3)}$ Program Studi Administrasi Bisnis, Fakultas Ilmu Administrasi dan Humaniora \\ Universitas Muhammadiyah Sukabumi \\ e-mail: desidp6@gmail.com ${ }^{1 *}$
}

\begin{abstract}
ABSTRAK
Penelitian ini bertujuan untuk mengetahui bagaimana metode zmijewski dapat digunakan dalam menganalisis financial distess pada PT. Jaya Konstruksi Manggala Pratama Tbk PT. Indonesia Pondasi Raya Tbk dan PT. Mitra Pemuda Tbk. Teknik analisis data yang digunakan adalah dengan menggunakan metode zmijewski. Hasil dari penelitian ini menunjukkan bahwa PT. Jaya Konstruksi Manggala Pratama Tbk, PT. Indonesia Pondasi Raya Tbk dan PT. Mitra Pemuda Tbk periode 2015-2017 berdasarkan metode zmijewski untuk menganalisis financial distress ketiga perusahaan berada dalam kondisi sehat atau non distress. Meskipun demikian perusahaan diharapkan dapat terus meningkatkan penjualan agar laba bersih yang diperoleh dapat meningkat setiap tahunnya dan harus mampu memenuhi kewajibannya agar total kewajiban dapat terus berkurang dan laba bersih terus bertambah setiap tahunnya. Sehingga perusahaan tidak akan mengalami financial distress.
\end{abstract}

Kata kunci: financial distress, laporan keuangan, metode zmijewski

\section{PENDAHULUAN}

Perusahaan merupakan suatu organisasi yang didirikan oleh perorangan maupun kelompok dengan menghasilkan produk atau jasa yang kemudian dapat menghasilkan keuntungan. Dalam menjaga kestabilan pendapatan, perusahaan harus menjaga produk atau jasa yang dihasilkan dengan cara menjaga kestabilan harga agar tidak mengalami kerugian. Setiap perusahaan manufaktur maupun jasa akan mengalami fase dimana tingkat penjualan yang bisa naik dan juga turun. Perusahaan yang mengalami tingkat penjualan yang naik akan memperoleh keuntungan besar sedangkan perusahaan yang mengalami penurunan penjualan akan memperoleh kerugian.

Kinerja keuangan perusahaan dapat berguna untuk mengukur tingkat keberhasilannya dalam menghasilkan laba sehingga perusahaan dapat melihat potensi juga pertumbuhan perusahaan. Hal ini dapat berguna bagi investor yang akan berinvestasi pada perusahaan karena dapat mengetahui kinerja keuangan perusahaan sehingga dapat melakukan pertimbangan terlebih dahulu sebelum melakukan investasi.

Investasi pada suatu perusahaan biasanya akan mengalami resiko ketidakpastian di waktu yang akan datang. Resiko yang dapat terjadi diantaranya tidak ada pengembalian 
investasi seperti yang diaharapkan karena perusahaan mengalami kesulitan keuangan (financial distress) yang disebakan dari kerugian yang di alami. Hal ini terjadi karena perusahaan tidak dapat melakukan jadwal pembayaran.

Financial distress dalam sebuah perusahaan dapat dialami karena manajemen yang tidak baik, kurangnya pengalaman atasan maupun bawahan dalam menjalankan perusahaan, kemampuan yang tidak sesuai, juga keterampilan yang terbatas. Banyaknya pesaing dalam sektor produk atau jasa yang dihasilkan serta sumber daya dan peralatan yang tidak memadai juga merupakan penyebab kebangkrutan.

PT. Jaya Konstruksi Manggala Pratama Tbk PT. Indonesia Pondasi Raya Tbk dan PT. Mitra Pemuda Tbk merupakan perusahaan yang bergerak dalam bidang konstruksi yang terdaftar di Bursa Efek Indonesia yang mengalami penurunan laba bersih pada periode 20152017. Berikut ini merupakan tabel pendapatan laba bersih periode 2015-2017:

Tabel 1. Pendapatan Laba Bersih Periode 2015-2017 (dalam jutaan rupiah

\begin{tabular}{lccc}
\hline \multicolumn{1}{c}{ Nama Perusahaan } & $\mathbf{2 0 1 5}$ & $\mathbf{2 0 1 6}$ & $\mathbf{2 0 1 7}$ \\
\hline PT. Jaya Konstruksi Manggala & 236.634 & 332.660 & 309.984 \\
$\quad$ Pratama Tbk & 227.799 & 120.413 & 114.258 \\
PT. Indonesia Pondasi Raya Tbk & 25.744 & 9.908 & 10.006 \\
PT. Mitra Pemuda Tbk & &
\end{tabular}

Sumber : Bursa Efek Indonesia

Dari tabel diatas PT. Jaya Konstruksi Manggala Prtama Tbk mengalami fluktuasi pada tahun 2015-2017, PT Indonesia Pondasi Raya Tbk mengalami penurunan laba pada tahun 2015-2017, dan PT. Mitra Pemuda mengalami fluktuasi pada tahun 2016-2017. Padahal laba bersih merupakan bagian terpenting dalam laporan keuangan yang menjadi tolak ukur keberhasilan perusahaan.

Untuk mengetahui apakah perusahaan mengalami financial distress (kesulitan keuangan) yang mengarah kedalam kebangkrutan dapat menggunakan berbagai metode analisis. Metode analisis yang dapat digunakan salah satunya adalah metode Zmijewski. Analisis financial distress ini cara menghitungnya cukup mudah dan juga cukup akurat. Analisis financial distress tersebut dapat digunakan perusahaan untuk penilaian dan juga pertimbangan terhadap kondisi perusahaan pada masa yang akan datang.

Metode Zmijewski oleh Mark Zmijewski pada tahun 1984 dan disebut dengan Zmijewski merupakan rumus yang diperoleh dari beberapa metode telah ada sebelumnya yang telah dikembangkan olehnya. Menurut Peter dan Yoseph (2011) Zmijewski menambah 
validitas rasio keuangan sebagai alat deteksi kegagalan keuangan perusahaan. Zmijewski melakukan studi dengan menelaah ulang bidang studi kebangkrutan hasil riset sebelumnya selama dua puluh tahun.

\section{METODE PENELITIAN}

Metode penelitian yang digunakan dalam penelitian ini merupakan metode deskriptif kuantitatif, yaitu dengan cara mengumpulkan, mengklasifikasikan, menganalisis, dan menginterprestasikan data-data yang diperoleh dari perusahaan sehingga dapat memberikan gambaran dengan keadaan yang sebenarnya (Arikunto, 2010).

Menurut Sugiyono (2013), metode deskriptif adalah metode yang mampu menjelaskan rumusan masalah yang berkenaan dengan pertanyaan terhadap keberadaan variabel mandiri, baik hanya satu variabel atau lebih (variabel mandiri adalah variabel yang berdiri sendiri, bukan variabel independen, karena variabel independen selalu dipasangkan dengan variabel dependen).

Data yang digunakan dalam penelitian ini merupakan data sekunder yaitu berupa dokumentasi dan studi kepustakaan. Dan data didapatkan secara tidak langsung dari perusahaan bersangkutan yang menjadi objek penelitian, melainkan dari sumber lain yaitu internet melalui situs resmi Bursa Efek Indonesia dengan alamat website www.idx.co.id

Teknik analisis data yang digunakan dalam penelitian ini adalah Metode Zmijewski. Menurut Kusumaningtyas (2017), Zmijewski dalam penelitiannya mensyaratkan satu hal yang krusial. Proporsi dari sampel dan populasi harus ditentukan di awal, sehingga didapat besaran frekuensi Financial Distress. Frekuensi ini diperoleh dengan membagi jumlah sampel yang mengalami Financial Distress dengan jumlah sampel keseluruhan (Rismawati, 2012). Metode Zmijewski pertama kali digunakan dalam penelitian pada 40 perusahaan bangkrut dan 800 perusahaan non-bangkrut. Berikut ini rumus yang dikemukakan Zmijewski (Dewi, 2015) :

X-Score $=-4,3-4,5 X 1+5,7 \mathrm{X} 2-0,004 \mathrm{X} 3$

Dimana :

$\mathrm{X} 1=$ EAT/Total Assets (Return On Assets)

$\mathrm{X} 2=$ Total Debt/Total Assets (Debt Ratio/Leverage)

X3 = Current Assets/Current Liabilities (Current Ratio atau Likuiditas)

Cut-off yang digunakan dalam model ini adalah 0, dimana jika hasil X-Score bernilai positif, maka perusahaan tersebut dikatakan tidak sehat. Sedangkan jika hasil X-Score bernilai negatif, maka perusahaan dikatakan sehat. Tingkat akurasi metode Zmijewski ini sebesar 94,9\%. (Purnajaya dan Merkusiwati, 2014) 


\section{HASIL DAN PEMBAHASAN}

Berdasarkan data yang di keluarkan oleh PT. Jaya Konstruksi Manggala Pratama Tbk PT. Indonesia Pondasi Raya Tbk dan PT. Mitra Pemuda Tbk melalui Bursa Efek Indonesia berupa laporan tahunan perusahaan selama tiga tahun terhitung tahun 2015-2017. Laporan tahunan tersebut mencakup laporan Dewan Komisaris, laporan Presiden Direktur, dan laporan keuangan perusahaan yang diperuntukan bagi pemegang saham dan pihak-pihak yang memiliki kepentingan dengan laporan tersebut.

Metode zmijewski merupakan metode yang dikembangkan oleh Zmijewski pada tahun 1985. Metode ini digunakan untuk mengetahui apakah perusahaan mengalami financial distress atau tidak. Dalam metode ini terdapat tiga indikator rasio keuangan yang dikombinasikan dalam sebuah rumus, yaitu earning after tax to total assets (Return On Assets), total debt to total assets (Debt Ratio atau Leverage), dan current assets to current liabilities (Current Ratio atau Likuiditas).

\section{Earning After Tax To Total Assets (X1)}

ROA merupakan rasio yang membandingkan laba bersih dengan total aset. Rasio ini digunakan untuk mengukur seberapa besar perusahaan dapat memanfaatkan aktivanya dalam memperoleh laba. Semakin besar ROA, semakin efisien penggunaan aktiva perusahaan, dan sebaliknya, semakin kecil ROA, maka penggunaan aktiva perusahaan semakin tidak efisien (Sudana, 2011).

Berdasarkan hasil perhitungan X1 pada PT. Jaya Konstruksi Manggala Pratama Tbk periode 2015-2017, perusahaan belum mampu menggunakan total aktiva secara efisien dalam menghasilkan laba karena hasil dari perhitungan laba bersih dibagi dengan total aktiva hasilnya menunjukan adanya fluktuasi. Dan hasil dari perhitungan X1 pada PT. Indonesia Pondasi Raya Tbk periode 2015-2017 dan PT. Mitra Pemuda Tbk periode 20152017, kedua perusahaan belum mampu menggunakan total aktiva secara efisien dalam

\section{Tabel 2. Hasil Perhitungan X1 pada PT. Jaya Konstruksi Manggala Pratama Tbk, PT. Indonesia Pondasi Raya Tbk dan PT. Mitra Pemuda Tbk}

\begin{tabular}{lccc}
\hline \multirow{2}{*}{ Nama Perusahaan } & \multicolumn{3}{c}{ Tahun } \\
\cline { 2 - 4 } & $\mathbf{2 0 1 5}$ & $\mathbf{2 0 1 6}$ & $\mathbf{2 0 1 7}$ \\
\hline PT. Jaya Konstruksi Manggala Pratama Tbk & 0,0621 & 0,0828 & 0,0738 \\
\hline PT. Indonesia Pondasi Raya Tbk & 0,1649 & 0,0778 & 0,0619 \\
\hline PT. Mitra Pemuda Tbk & 0,2195 & 0,0382 & 0,0382 \\
\hline
\end{tabular}


menghasilkan laba karena hasil dari perhitungan laba bersih dibagi dengan total aktiva menunujukan adanya penurunan. Hal ini disebabkan karena laba bersih mengalami fluktuasi dan total aktiva mengalami penurunan.

\section{Total Debt To Total Assets (X2)}

Debt ratio atau leverage merupakan rasio yang membandingkan antara total hutang dengan total aset. Rasio ini digunakan untuk mengukur likuiditas perusahaan secara keseluruhan. Semakin besar rasio ini, maka semakin besar pula penggunaan utang dalam membiayai investasi pada aktiva, yang berarti risiko keuangan perusahaan juga semakin meningkat.

Tabel 3. Hasil perhitungan X2 pada PT. Jaya Konstruksi Manggala Pratama Tbk, PT. Indonesia Pondasi Raya Tbk dan PT. Mitra Pemuda Tbk

\begin{tabular}{lccc}
\hline \multirow{2}{*}{ Nama Perusahaan } & \multicolumn{3}{c}{ Tahun } \\
\cline { 2 - 4 } & $\mathbf{2 0 1 5}$ & $\mathbf{2 0 1 6}$ & $\mathbf{2 0 1 7}$ \\
\hline PT. Jaya Konstruksi Manggala Pratama Tbk & 0,4898 & 0,4508 & 0,4282 \\
\hline PT. Indonesia Pondasi Raya Tbk & 0,2815 & 0,2848 & 0,3434 \\
\hline PT. Mitra Pemuda Tbk & 0,8082 & 0,5225 & 0,4889
\end{tabular}

Sumber : Diolah oleh peneliti, 2019

Hasil dari perhitungan X2 pada PT. Jaya Konstruksi Manggala Pratama Tbk periode 20152107, perusahaan berada dalam kondisi keuangan yang baik karena hasil dari total kewajiban dibagi dengan total aktiva menunjukan adanya penurunan. Hal ini disebabkan karena total kewajiban mengalami penurunan dan total aktiva mengalami kenaikan. Lalu hasil dari perhitungan X2 pada PT. Indonesia Pondasi Raya Tbk periode 2015-2017, perusahaan berada dalam kondisi keuangan yang kurang baik karena hasil total kewajiban dibagi dengan total aktiva menunjukan adanya kenaikan. Hal ini disebabkan karena total kewajiban dan total aktiba mengalami kenaikan. Dan hasil dari perhitungan X2 pada PT. Mitra Pemuda Tbk periode 2015-2017 perusahaan berada dalam kondisi keuangan yang baik karena hasil dari total kewajiban dibagi dengan total aktiva menunjukkan adanya penurunan. Hal ini disebabkan karena total kewajiban mengalami fluktuasi dan total aktiva yang mengalami kenaikan.

\section{Current Assets To Current Liabilities (X3)}

Current ratio atau likuiditas merupakan rasio yang membandingkan aktiva lancar dengan kewajiban lancar. Rasio ini digunakan untuk mengukur tingkat likuiditas perusahaan. 
Likuiditas perusahaan sudah dapat dianggap baik jika nilai rasio lancarnya sama dengan 2 . Semakin tinggi hasil perhitungan rasio ini maka semakin terjamin hutang-hutang perusahaan kepada kreditur, karena bagi kreditur semakin tinggi nilai rasio ini semakin bagus.

Tabel 4. Hasil perhitungan X3 pada PT. Jaya Konstruksi Manggala Pratama Tbk, PT. Indonesia Pondasi Raya Tbk dan PT. Mitra Pemuda Tbk

\begin{tabular}{lccc}
\hline \multirow{2}{*}{ Nama Perusahaan } & \multicolumn{3}{c}{ Tahun } \\
\cline { 2 - 4 } & $\mathbf{2 0 1 5}$ & $\mathbf{2 0 1 6}$ & $\mathbf{2 0 1 7}$ \\
\hline PT. Jaya Konstruksi Manggala Pratama Tbk & 1,6487 & 1,6929 & 1,7037 \\
\hline PT. Indonesia Pondasi Raya Tbk & 3,1395 & 2,6180 & 2,7039 \\
\hline PT. Mitra Pemuda Tbk & 1,4370 & 1,6911 & 1,7667 \\
\hline
\end{tabular}

Sumber : Diolah oleh peneliti, 2019

Hasil dari perhitungan X3 pada PT. Jaya Konstruksi Manggala Pratama Tbk periode 20152017. Tingkat likuiditas perusahaan berada dalam kondisi tidak baik karena likuiditas perusahaan akan dianggap baik jika hasil perhitungan X3 adalah 2. Lalu hasil dari perhitungan X3 pada PT. Indonesia Pondasi Raya Tbk periode 2015-2017. Tingkat likuiditas perusahaan berada dalam kondisi yang baik sehingga perusahaan mampu menutupi kewajiban nya meskipun hasil perhitungan X3 mengalami fluktuasi. Dan hasil dari perhitungan X3 pada PT. Mitra Pemuda Tbk periode 2015-2017. Tingkat likuiditas perusahaan berada dalam kondisi tidak baik karena likuiditas perusahaan akan dianggap baik jika hasil perhitungan X3 adalah 2.

Tabel 5. Hasil Perhitungan Financial Distress Dengan Metode Zmijewski pada PT. Jaya Konstruksi Manggala Pratama Periode 2015-2017

\begin{tabular}{ccccccc}
\hline Tahun & & $4,5(\mathrm{X} 1)$ & $5,7(\mathrm{X} 2)$ & $0,004(\mathrm{X} 3)$ & $\mathrm{X}-$ Score & Hasil Prediksi \\
\hline 2015 & $-4,3$ & 0,0621 & 0,4898 & 1,6487 & $-1,7942$ & Non Distress \\
\hline 2016 & $-4,3$ & 0,0828 & 0,4508 & 1,6929 & $-2,1098$ & Non Distress \\
\hline 2017 & $-4,3$ & 0,0738 & 0,4282 & 1,7037 & $-2,1982$ & Non Distress \\
\hline
\end{tabular}

Sumber : Diolah oleh peneliti, 2019

PT. Jaya Konstruksi Manggala Pratama Tbk pada tahun 2015 memperoleh nilai X-Score sebesar -1,7942 sehingga perusahaan dikategorikan non distress karena pada metode zmijewski jika hasil X-Score negatif maka perusaaan dikategorikan non distress. Pada tahun 2016 PT. Jaya Konstruksi Manggala Pratama Tbk memperoleh nilai X-Score sebesar -2,1908 sehingga perusahaan dikategorikan non distress. Terjadi penurunan nilai X-Score pada tahun 2016 dan ini berdampak baik bagi perusahaan. Penurunan terjadi karena 
naiknya nilai X1 yang disebabkan oleh kenaikan laba usaha dan penurunan pada nilai X2 terjadi karena kenaikan total aset. Dan pada tahun 2017 PT. Jaya Konstruksi Manggala Pratama Tbk memperoleh nilai X-Score -2,1982. Pada tahun 2017 nilai X-Score mengalami penurunan dari tahun sebelumnya, hal ini berdampak baik bagi perusahaan. Penurunan terjadi karena X1 dan X2 mengalami penurunan dan X3 mengalami peningkatan. Penurunan pada X1 dan X2 disebabkan oleh naiknya total aset dan peningkatan pada X3 disebabkan oleh menurunnya kewajiban lancar pada perusahaan. Jadi PT. Jaya Konstruksi Manggala Pratama Tbk periode 2015-2017 perusahaan berada dalam keadaan sehat atau non distress, namun perusahaan harus tetap menjaga kestabilan keuangan perusaaan seperti meningkatnya penjualan sehingga laba bersih yang diperoleh akan mengalami peningkatan dan perusahaan harus mampu memenuhi kewajibannya.

Tabel 6. Hasil Perhitungan Financial Distress dengan Metode Zmijewski pada PT. Indonesia Pondasi Raya Tbk Periode 2015-2017

\begin{tabular}{ccccccc}
\hline Tahun & & $4,5(\mathrm{X} 1)$ & $5,7(\mathrm{X} 2)$ & $0,004(\mathrm{X} 3)$ & $\mathrm{X}-$ Score & Hasil Prediksi \\
\hline 2015 & $-4,3$ & 0,1649 & 0,2815 & 3,1395 & $-3,4501$ & Non Distress \\
\hline 2016 & $-4,3$ & 0,0778 & 0,2848 & 2,6180 & $-3,0372$ & Non Distress \\
\hline 2017 & $-4,3$ & 0,0619 & 0,3434 & 2,7039 & $-2,6319$ & Non Distress \\
\hline
\end{tabular}

Sumber : Diolah oleh peneliti, 2019

PT. Indonesia Pondasi Raya Tbk pada tahun 2015 memperoleh nilai X-Score sebesar 3,4501 sehingga perusahaan dikategorikan non distress. Pada tahun 2016 PT. Indonesia Pondasi Raya Tbk memperoleh nilai X-Score sebesar -3,0372. Terjadi peningkatan nilai XScore pada tahun 2016 dibandingkan tahun 2015 disebabkan oleh penurunan nilai X1 dan X3 dan peningkatan pada nilai X2. Penurunan pada X1 terjadi karena naiknya total aset, peningkatan pada X2 terjadi karena naiknya total kewajiban, dan penurunan pada X3 terjadi karena naiknya kewajiban lancar. Dan pada tahun 2017 PT. Indonesia Pondasi Raya Tbk memperoleh nilai X-Score sebesar -2,6319. Pada tahun 2017 terjadi peningkatan nilai X-Score pada PT. Indonesia Pondasi Raya Tbk, hal ini disebabkan oleh penurunan nilai X1 dan peningkatan pada nilai X2 dan X3. Penurunan pada X1 terjadi karena naiknya total aset, peningkatan pada X2 terjadi karena naiknya total kewajiban dan peningkatan pada X3 terjadi karena naiknya nilai aset lancar. Jadi PT. Indonesia Pondasi Raya Tbk periode 2015-2017 dikategorikan sehat atau non distress, akan tetapi terjadi peningkatan nilai XScore setiap tahunnya dan ini berdampak buruk bagi perusahaan, sehingga perusahaan harus meningkatkan penjualan agar laba bersih yang diperoleh meingkat setiap tahunnya 
dan kewajiban lancar harus mengalami penurunan setiap tahunnya dengan mengurangi pinjaman karena jika total kewajiban terus meningkat dan perusahaan tidak mampu membayarnya maka perusahaan dapat mengarah kedalam financial distress. Dan jika perusahaan mengalami peningkatan nilai X-Score pada tahun selanjutnya dan nilai yang diperoleh adalah positif maka perusahaan dapat dikategorikan tidak sehat atau distress.

Tabel 7. Hasil Perhitungan Financial Distress Dengan Metode Zmijewski pada PT. Mitra Pemuda Tbk Peride 2015-2017

\begin{tabular}{ccccccc}
\hline Tahun & & $4,5(\mathrm{X} 1)$ & $5,7(\mathrm{X} 2)$ & $0,004(\mathrm{X} 3)$ & $\mathrm{X}$-Score & Hasil Prediksi \\
\hline 2015 & $-4,3$ & 0,2195 & 0,8082 & 1,4370 & $-0,6868$ & Non Distress \\
\hline 2016 & $-4,3$ & 0,0382 & 0,5225 & 1,6911 & $-1,5004$ & Non Distress \\
\hline 2017 & $-4,3$ & 0,0382 & 0,4889 & 0,7667 & $-1,6882$ & Non Distress \\
\hline
\end{tabular}

Sumber : Diolah oleh peneliti, 2019

PT. Mitra Pemuda Tbk pada tahun 2015 memperoleh nilai X-Score sebesar -0,6868 sehingga perusahaan dikategorikan sehat atau non distress. Pada tahun 2016 PT. Mitra Pemuda memperoleh nilai X-Score sebesar -1,5004. Terjadi penurunan nilai X-Score pada tahun 2016 dibandingkan tahun sebelumnya yang disebabkan oleh penurunan nilai X1 dan X2 dan peningkatan nilai X3. Penurunan pada nilai X1 dan X2 disebabkan oleh naiknya total aset dan peningkatan pada X3 disebabkan oleh turunnya kewajiban lancar. Dan pada tahun 2017 PT. Mitra Pemuda Tbk memperoleh nilai X-Score sebesar -1,6882. Terjadi penurunan nilai X-Score pada PT. Mitra Pemuda Tbk dibandingkan tahun sebelumnya yang disebabkan oleh penurunan nilai X2 dan peningkatan pada nilai X3. Penurunan pada X2 terjadi karena naiknya total aset dan peningkatan pada X3 disebabkan oleh naiknya aset lancar. Jadi PT. Mitra Pemuda Tbk periode 2015-2017 berada dalam kategori sehat atau non distress. Akan tetapi jika perusahaan terus mengalami peningkatan total kewajiban dan kewajiban lancar maka perusahaan dapat mengarah kedalam kondisi financial distress. Sehingga perusahaan harus terus meningkatkan penjualan pada setiap tahunnya untuk memperoleh laba bersih yang besar dan dapat memenuhi kewajibannya agar hasil laba bersih yang diperoleh tidak menurun.

\section{KESIMPULAN DAN SARAN}

\section{Kesimpulan}

Berdasarkan hasil dan pembahasan yang telah dijelaskan diatas mengenai Analisis Financial Distress Pada PT. Jaya Konstruksi Manggala Pratama Tbk PT. Indonesia Pondasi 
Raya Tbk dan PT. Mitra Pemuda Tbk periode 2015-2017 dengan menggunakan metode zmijewski ketiga perusahaan tersebut masuk dalam kategori sehat atau non distress. Perusahaan dikategorikan non distress, karena hasil X-Score yang diperoleh adalah negatif. Akan tetapi perusahaan harus bisa memenuhi kewajibannya dan mengurangi kewajiban setiap tahunnya agar tidak mengarah kedalam financial distress. Perusahaan harus terus meningkatkan penjualan setiap tahunnya agar laba bersih yang diperoleh lebih besar dari kewajiban perusahaan.

\section{Saran}

Perusahaan diharapkan dapat menjaga kestabilan kondisi keuangan perusahan seperti meningkatkan hasil penjualan sehingga laba bersih yang diperoleh meningkat setiap tahunya serta harus mampu memenuhi kewajibannya agar total kewajiban dapat berkurang setiap tahunnya. Dengan demikian perusahaan tidak akan mengalami kesulitan keuangan (financial distress) yang dapat mengarah kedalam kebangkrutan, karena kondisi keuangan perusahaan berada dalam kondisi yang baik.

\section{REFERENSI}

Arikunto, Suharsimi. 2010. Prosedur Penelitian, Edisi Revisi. Yogyakarta: Rineka Cipta.

Kusumaningtyas, Dega. 2017. Analisis Prediksi Kebangkrutan Dengan Menggunakan Model Zmijewski, Springate Dan Fulmer Pada Perusahaan Ritel Di Bursa Efek Indonesia. Artikel Ilmiah. STIE Perbanas Surabaya. Jurusan Akuntansi Keuangan.

Peter dan Yoseph. 2011. Analisis Kebangkrutan Dengan Metode Z-Score Altman, Springate dan Zmijewski Pada PT. Indofood Sukses Makmur Tbk Periode 2005 2009. Jurusan Manajemen, Universitas Kristen Maranatha. Akurat Jurnal Ilmiah Akuntansi. Nomor 04 Tahun ke-2

Purnajaya, K. D. M., \& Merkusiwati, N. K. L. A. 2014. Analisis Komparasi Potensi Kebangkrutan dengan Metode Z-Score Altman, Springate, dan Zmijewski pada Industri Kosmetik yang Terdaftar di Bursa Efek Indonesia. E-Jurnal Akuntansi. Vol.7. No.1. Hal: 48-63

Sudana, I Made. 2011. Manajemen Keuangan Perusahaan Teori dan Praktik. Jakarta: Erlangga.

Sugiyono. 2016. Metode Penelitian Kuantitatif Kualitatif. Bandung: Alfabeta 